\title{
EFFECT OF DIRECT COOLING CONDITIONS ON THE MICROSTRUCTURE AND PROPERTIES OF HOT-FORGED HSLA STEELS FOR MINING APPLICATIONS
}

\author{
VPLIV POGOJEV OHLAJANJA NA MIKROSTRUKTURO IN \\ LASTNOSTI VROČE KOVANIH HSLA JEKEL ZA UPORABO V \\ RUDARSTVU
}

\author{
Piotr Skubisz, Lukasz Lisiecki, Tadeusz Skowronek, Artur Żak, Władysław Zalecki \\ ${ }^{1}$ AGH University of Science and Technology, Department of Metals Engineering and Industrial Computers Science, 30A Mickiewicz Ave, \\ Kracow, Poland \\ ${ }^{2}$ Ferrous Metals Institute, 12-14 K. Miarki, Gliwice, Poland \\ pskubisz@metal.agh.edu.pl \\ Prejem rokopisa - received: 2015-09-18; sprejem za objavo - accepted for publication: 2015-10-26
}

doi:10.17222/mit.2015.298

\begin{abstract}
The article presents hot deformation and controlled direct cooling of hardened medium-carbon HSLA steel with micro-additions of alloying elements Ti and/or V. It also contains a study of the effect of thermomechanical-processing conditions on grain refinement and precipitation kinetics in the replacement of the conventional reheating-requiring heat treatment with a cost-effective technology. Controlled cooling with accelerated air and mist adjusted to lower carbon and hardenability-related alloying elements by means of employing experimentally designed heats, varying in the Mo content, was designed to meet the mining-industry requirements for mechanical properties. Besides microstructural-property relations, the vital problem of non-uniformity of the obtained properties is addressed with regard to within-part variances in the cooling rate of the as-forged, undeformed and dynamically recrystallized material. The strength and plasticity versus the microstructure of the produced fine pearlite/bainite structure with grain-boundary ferrite were evaluated. Microstructure-property relations allowed the formulation of the conclusions on the effect of direct-cooling conditions on the microstructure and grain substructure, their mutual synergic effect in controlling the microstructure, as well as guidelines for the transfer of the locally established process parameters into technological conditions.

Keywords: thermomechanical processing, drop forging, accelerated cooling, grain refinement, tempered martensite
\end{abstract}

Članek predstavlja vročo deformacijo in kontrolirano ohlajanje srednjeogljičnega HSLA jekla z mikrododatkom legirnih elementov $\mathrm{Ti}$ in/ali V. Vsebuje tudi študijo vpliva pogojev termomehanske obdelave na udrobnjenje zrn in kinetiko izločanja pri nadomeščanju običajnega režima ogrevanja za toplotno obdelavo s cenejšo tehnologijo. Da bi dosegli zahteve rudarske industrije in mikrostrukturne lastnosti, je bilo vzpostavljeno kontrolirano ohlajanje s tokom zraka in mešanice zraka ter vode, prilagojeno nižjemu ogljiku in drugim elementom. Ti vplivajo na prekaljivost $\mathrm{z}$ uporabo eksperimentalnih talin, $\mathrm{v}$ katerih se je spreminjala vsebnost Mo. Poleg odvisnosti lastnosti od mikrostrukture, je glavni problem neenakost dobljenih lastnosti, kar je delno povezano $\mathrm{z}$ razlikami pri ohlajanju v kosu kovanega, nedeformiranega ali dinamično rekristaliziranega materiala. Ocenjeni sta bili trdnost in plastičnost v odvisnosti od nastale drobnozrnate perlitno/bainitne mikrostrukture s feritom po mejah zrn. Odvisnost mikrostrukture od lastnosti omogoča postavitev zaključkov o vplivu pogojev pri neposrednem ohlajanju na mikrostrukturo in zrna substrukture ter njihov medsebojni vpliv pri kontroli mikrostrukture, kot tudi navodila za prenos lokalno ugotovljenih procesnih parametrov v tehnološke pogoje.

Ključne besede: termomehanska obdelava, kovanje s padalnim kladivom, pospešeno ohlajanje, zmanjšanje zrn, popuščen martenzit

\section{INTRODUCTION}

Forging has long been more than a mere shaping technique. In addition to the accuracy requirements, such as allowances and yield, mechanical properties must be fulfilled. As an alternative to the traditional quenching and tempering (Q\&T) heat treatment, thermomechanical processing (TMP) in controlled conditions of forging and direct cooling is increasingly used on an industrial scale, offering a good combination of strength and ductility at a lower cost. ${ }^{1-3}$

The strength levels obtained with TMP are often lower as compared to a traditional Q\&T material ${ }^{4}$, due to an excessive surplus of indices in the case of the latter. Furthermore, some mechanical properties of TMP mi- croalloyed grades, such as the fatigue strength, are second to those treated with Q\&T. ${ }^{5}$ The key issue is to control the chemistry and processing cycle so as to achieve the sustainable strength, plasticity, cracking and/or fatigue resistance required by the end user of a finished product.

Thus, numerous microalloyed grades for specific applications have been designed over the decades. So have the technologies of forging and subsequent cool ing. ${ }^{6,7}$ This work is devoted to the design or modification of a microalloyed steel grade exhibiting as-forged aircooled mechanical properties suitable for a mining application. The target application of this combination is a miners' linking hook for coal transport, which, after a 
controlled hot-forging and direct heat treatment, involving quenching and self-tempering, is expected to provide a yield strength $(Y S)$ of $800 \mathrm{MPa}$, the ultimate tensile strength (UTS) of $1050 \mathrm{MPa}$, an elongation to fracture of A $15 \%$ and/or an impact strength at room temperature of $\mathrm{KCV} 60 \mathrm{~J} / \mathrm{cm}^{2}$ to substitute C45 or SJ355 heat-treatable structural steel grades.

\section{EXPERIMENTAL METHODS}

The research plan included testing the effect of forging temperature on the microstructure and mechanical properties obtained after direct cooling in forced air and atomizers, applied to designed microalloyed grades, hot deformed in an inconvenient high-speed hammer-forging process. The goal of the study was both the investigation of the effect of material-process conditions on the final (as-forged) properties, and its applicability to drop-forging industrial conditions with respect to the uniformity of the properties.

Eight different sets of alloying elements were composed on the basis of the computation in Thermocalc under equilibrium thermodynamics conditions. Diagrams were established on the basis of a volumetric-change analysis (dilatometer DIL 805 with probe LVDT) CTT, followed by an examination of the microstructures obtained with different cooling rates of $0.17{ }^{\circ} \mathrm{C} / \mathrm{s}$, $0.42{ }^{\circ} \mathrm{C} / \mathrm{s}, 1{ }^{\circ} \mathrm{C} / \mathrm{s}, 2{ }^{\circ} \mathrm{C} / \mathrm{s}, 4{ }^{\circ} \mathrm{C} / \mathrm{s}, 10{ }^{\circ} \mathrm{C} / \mathrm{s}, 20{ }^{\circ} \mathrm{C} / \mathrm{s}$, $40{ }^{\circ} \mathrm{C} / \mathrm{s}, 50{ }^{\circ} \mathrm{C} / \mathrm{s}$ and $100{ }^{\circ} \mathrm{C} / \mathrm{s}$, taking into consideration the cooling rates predicted in the modeling of physical cooling of the target geometry. Having had selected two grades, further described as A and B, laboratory tests of rolling and direct cooling with water and air were conducted, as well as forging on a hydraulic press of $5 \mathrm{MN}$ with a ram velocity of $50 \mathrm{~mm} / \mathrm{s}$.

To estimate the amount of deformation and the actual forge-end temperature in the bulk of the part, a numerical calculation of an equivalent strain and temperature progression in hot forging was carried out. Since the forging temperature should be high enough to dissolve carbides and carbonitrides so as to enable their precipi-

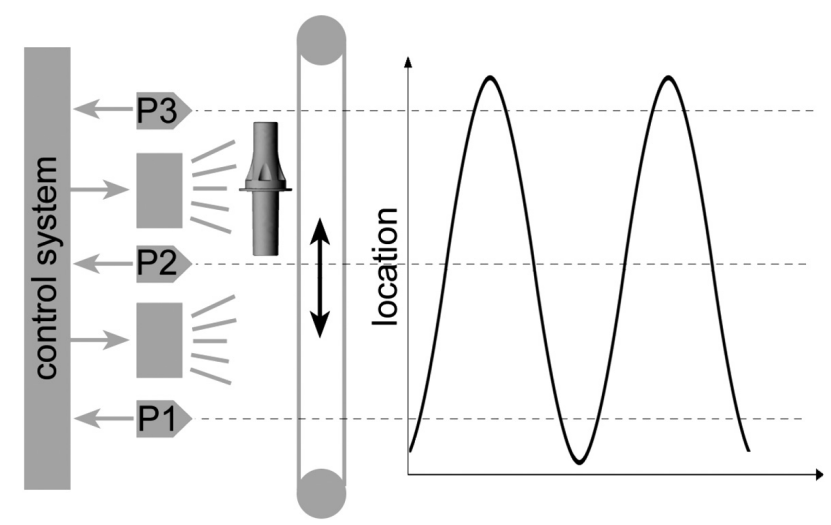

Figure 1: Laboratory simulation of the cooling line Slika 1: Laboratorijski simulator linije ohlajanja tation during the post-forging direct cooling, a soaking temperature of $1190{ }^{\circ} \mathrm{C}$ was established and forging temperatures ranging between $(1100,1000$ and 900$){ }^{\circ} \mathrm{C}$ were assumed. The cooling rate - fast enough to provide harder microstructural components during the subsequent cooling 8 - was realized with atomizers.

Numerical modeling was conducted with the finiteelement method (FEM) in code QForm3D. Besides supplying the data for the prediction of transformation products or microstructural development, and carbide and carbonitride precipitation kinetics, the results of the calculation formed the basis for experimental controlled cooling tests on a laboratory continuous cooling line, QuenchTube Duo (Figure 1).

The laboratory cooling line simulated an industrial cooling line, providing a forced stream of mist with intervals resulting from the transfer of a part between consecutive cooling zones. All runs involved the same cycle, irrespective of the forging temperature and the alloy. Cooling was conducted at a cooling rate adapted to the temperature changes, calculated for a drop-forged miners' link hook (Figure 2), which formed a case study for an evaluation of the effectiveness of the selected processing conditions with respect to the forging temperature and chemical composition.

\section{MATERIALS}

The study involved experimentally designed steel grades, which were to provide directly cooled forgings with the mechanical properties comparable to typical mining-industry grades, such as $\mathrm{C} 45,41 \mathrm{Cr}, 36 \mathrm{CrNiMo} 4$ and $23 \mathrm{MnNiCrMo5}$.

Eight grades were made, based on the assumption of a reduction of carbon and the major alloying elements, and micro-additions of $\mathrm{Ti}, \mathrm{V}$ and $\mathrm{Nb}$, with or without Mo. The heating was performed in an induction-heating vacuum furnace, VSG-100, with a $100 \mathrm{~kg}$ nominal capacity of the melting pot. Thermodynamic stability and volume fractions of phase components and precipitates were calculated in Thermocalc and confirmed with a dilatometric analysis. Upon the investigation of the primary and transformed austenite grain size, the predicted or calculated yield and impact strength, two grades were

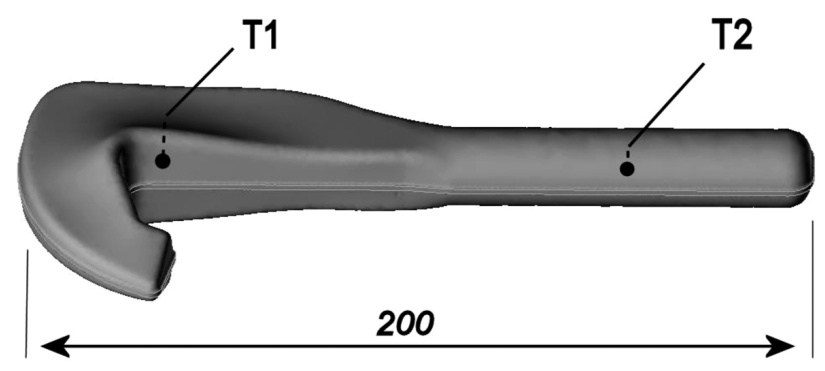

Figure 2: Geometry of the target application; T1, T2 - thermocouple locations

Slika 2: Geometrija preizkušanca; T1, T2 - lokacija termoelementov 
Table 1: Chemical compositions of experimental heats of microalloyed steels used in the study Tabela 1: Kemijska sestava eksperimentalnih talin mikrolegiranih jekel, uporabljenih v študiji

\begin{tabular}{|c|c|c|c|c|c|c|c|c|c|c|c|}
\hline Steel & $\% \mathrm{C}$ & $\% \mathrm{Mn}$ & $\% \mathrm{Cr}$ & $\% \mathrm{Si}$ & $\% \mathrm{Mo}$ & $\% \mathrm{Ti}$ & $\% \mathrm{~V}$ & $\% \mathrm{Nb}$ & $\% \mathrm{~N}$ & $A c_{1},{ }^{\circ} \mathrm{C}$ & $\mathrm{Ac}_{3},{ }^{\circ} \mathrm{C}$ \\
\hline A & 0.30 & 1.50 & 0.42 & 0.26 & 0 & 0.011 & 0.09 & 0.039 & 0.011 & 809 & 785 \\
\hline B & 0.28 & 1.24 & 0.42 & 0.27 & 0.2 & 0.019 & 0.067 & 0.047 & 0.010 & 728 & 727 \\
\hline
\end{tabular}

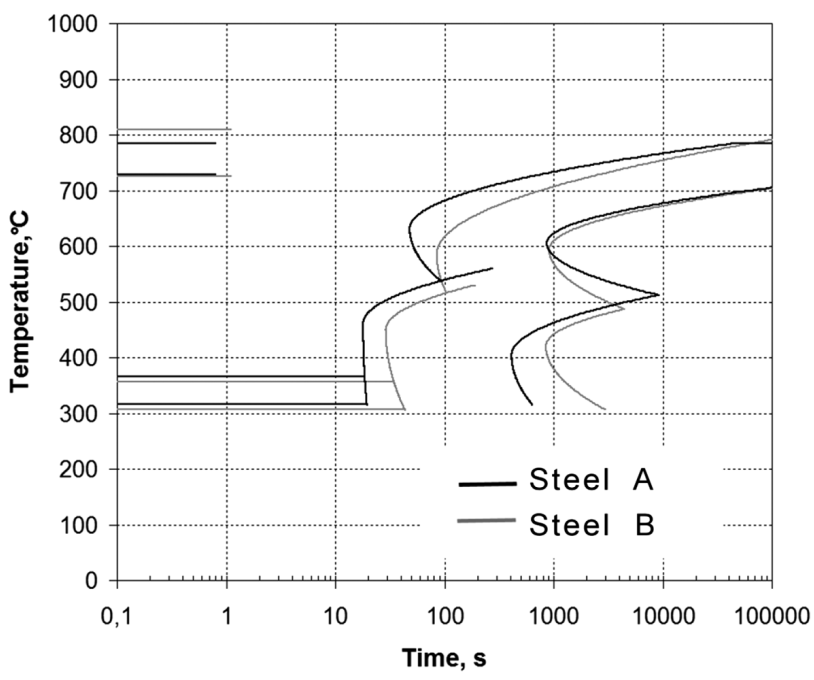

Figure 3: Continuous-cooling diagrams calculated with TTSteel code, modified with theoretical equations 9

Slika 3: Diagram kontinuiranega ohlajanja, izračunan s TTSteel kodo in spremenjen s teoretičnimi enačbami ${ }^{9}$

selected (Table 1), indicating the smallest grain size and a potential combination of strength and ductility. Utilizing the deformed material from plastometric tests with formulas for characteristic times, ${ }^{9}$ continuous-cooling-transformation diagrams (CCT) of non-recrystallized materials were made, as shown in Figure 3.

\section{RESULTS AND EVALUATION}

\subsection{Analysis of the target forging technology}

Forging-machine kinematics has an enormous impact on thermomechanical parameters for a hot-forged piece. As could be expected, hammer forging produces an increased amount of generated heat and temperature gradients, which influence the flow stress and metal dis- placement. Numerical modeling with FEM allowed for an estimate of the level, variance and gradients of the temperature and strain development during the forging. This information made it possible to evaluate the obtained results of direct cooling where, unlike for the traditionally heat-treated material, the as-forged steel inherits the aftermath of dynamic processes. Thus, to fit the laboratory-test results to the target application, we carried out an insightful analysis of the development of the thermomechanical indicators of the changes influencing the final microstructure and properties.

The results of the FEM analysis are summarized in Table 2.

Table 2: Evolution of thermo-mechanical conditions in the forged part (in locations shown in Figure 2)

Tabela 2: Razvoj termo-mehanskih pogojev v kovanem kosu (na mestih prikazanih na Sliki 2)

\begin{tabular}{|c|c|c|c|c|c|c|}
\hline \multicolumn{2}{|c|}{ Operation } & 1 & 2 & 3 & 4 & 5 \\
\hline \multirow{2}{*}{ Effective strain } & $\mathrm{T} 1$ & 0.62 & 0.62 & 0.62 & 0.84 & 0.88 \\
\cline { 2 - 7 } & $\mathrm{T} 2$ & 0.62 & 1.25 & 2.51 & 2.75 & 2.81 \\
\hline \multirow{2}{*}{ Temp., ${ }^{\circ} \mathrm{C}$} & $\mathrm{T} 1$ & 1115 & 1107 & 1089 & 1105 & 1090 \\
\cline { 2 - 6 } & $\mathrm{T} 2$ & 1115 & 1130 & 1136 & 1144 & 1140 \\
\hline
\end{tabular}

\subsection{Effect of the cooling rate}

To assess the dependence of the structural components and the grain size on the cooling rate, the microstructure derived from a dilatometric investigation of normalized material was examined. Micrographs obtained for both alloys are shown in Figures $\mathbf{4}$ and $\mathbf{5}$.

\subsection{Physical modeling of forging and cooling}

The effect of the run-out table temperature on the kinetics of austenite restoration and precipitation of carbides and carbonitrides, and the resulting strengthening
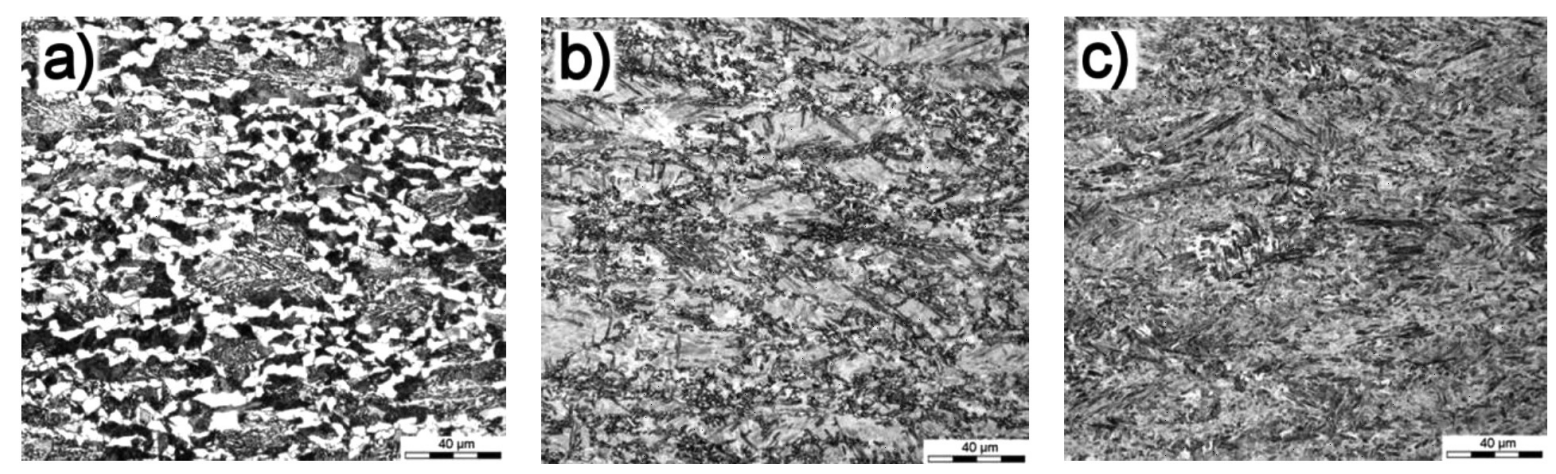

Figure 4: Microstructure of as-received (hot-rolled) alloy A after anisothermal cooling at rates: a) $\left.\left.1{ }^{\circ} \mathrm{C} / \mathrm{s}, \mathrm{b}\right) 10{ }^{\circ} \mathrm{C} / \mathrm{s}, \mathrm{c}\right) 50{ }^{\circ} \mathrm{C} / \mathrm{s}$ Slika 4: Mikrostruktura izhodne (vroče valjane) zlitine A, po anizotermnem ohlajanju s hitrostjo: a) $1{ }^{\circ} \mathrm{C} / \mathrm{s}, \mathrm{b}$ ) $10{ }^{\circ} \mathrm{C} / \mathrm{s}, \mathrm{c}$ ) $50{ }^{\circ} \mathrm{C} / \mathrm{s}$ 

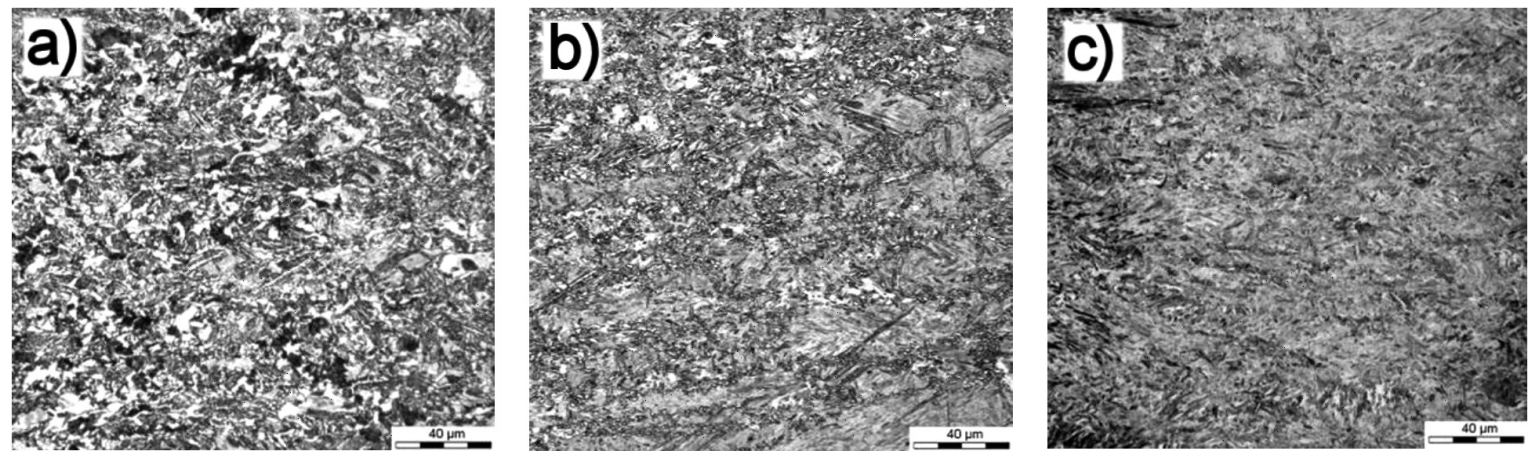

Figure 5: Microstructure of as-received (hot-rolled) alloy B after anisothermal cooling at rates: a) $1{ }^{\circ} \mathrm{C} / \mathrm{s}, \mathrm{b}$ ) $10{ }^{\circ} \mathrm{C} / \mathrm{s}, \mathrm{c}$ ) $50{ }^{\circ} \mathrm{C} / \mathrm{s}$ Slika 5: Mikrostruktura izhodne (vroče valjane) zlitine $\mathrm{B}$, po anizotermnem ohlajanju s hitrostjo: a) $1{ }^{\circ} \mathrm{C} / \mathrm{s}$, b) $10{ }^{\circ} \mathrm{C} / \mathrm{s}$, c) $50{ }^{\circ} \mathrm{C} / \mathrm{s}$

efficiency was investigated by varying the forging temperature while employing the same cooling conditions after the deformation.

According to the plots of temperature measured during the experiments, the assumed temperatures changed during the deformation and therefore the forge end temperature was not exactly the same as expected. Due to a non-uniform distribution of strain in the bulk, the amount of generated deformation heat varied with the location (Table 2). However, the assumed temperatures of forging, (1100, 1000 and 900) ${ }^{\circ} \mathrm{C}$, allowed an analysis of the material response in the representative ranges in relation to the temperatures of the dynamicrecrystallization stop and the solution of carbonitrides/
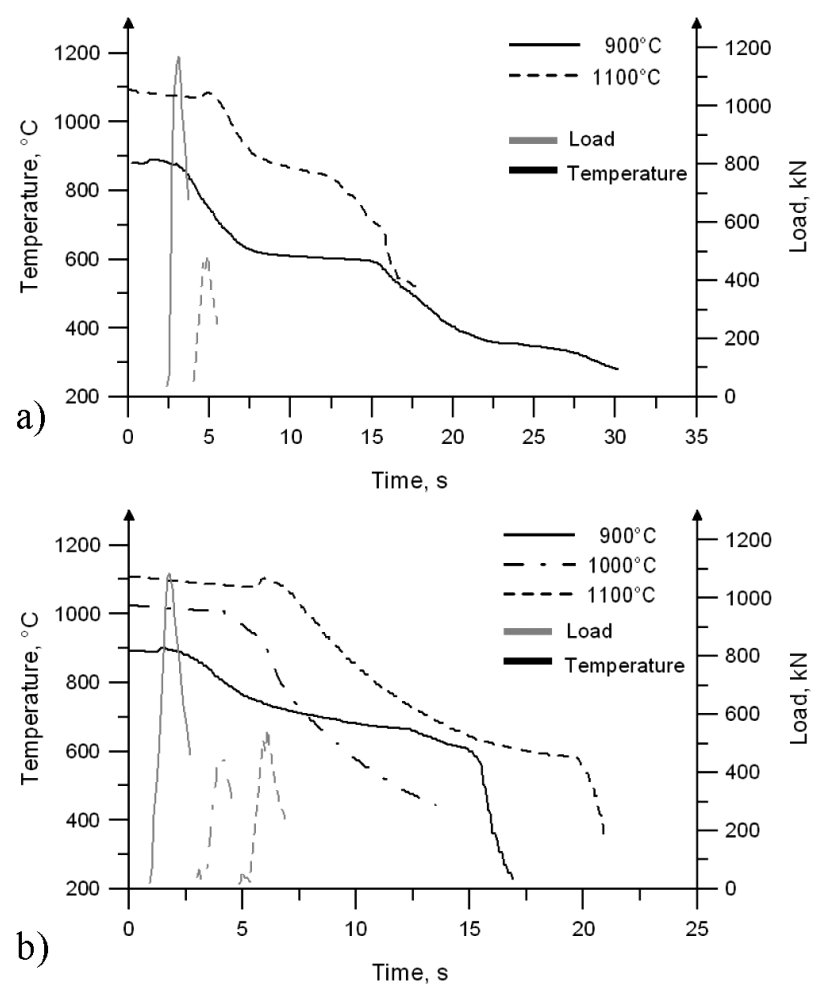

Figure 6: Experimental cooling-curve plots for: a) steel A, and b) steel B; load peaks (grey) indicate forge-end points

Slika 6: Diagrami eksperimentalnih krivulj ohlajanja: a) jeklo A in b) jeklo B; konice obremenitve (siva barva) kažejo konec kovanja carbides. The highest temperature, assumed for the total content of carbon and microalloying elements, was found in the solution, available for precipitation. The lowest forging temperature of $900{ }^{\circ} \mathrm{C}$ dropped to $880{ }^{\circ} \mathrm{C}$ due to the material transfer and die cooling; it was meant to provide the alloys with a reasonable amount of accumulated strain, based on the calculated recrystallization stop temperature. The forging at $1000{ }^{\circ} \mathrm{C}$ was to show the effect of the precipitates formed prior to forging on the evolution of dynamically recrystallized grains. As alloy B did not contain Mo, this test was conducted for alloy A only.

The obtained cooling curves are shown in Figure 6 for steels A and B, respectively. For clarity, the plots were shifted and the moment of deformation was indicated by plotting the forging load (in grey). This was also an opportunity to indicate unexpected dependence of the load extreme on the temperature for steel B, which shows a higher value at $1000{ }^{\circ} \mathrm{C}$ than at $900{ }^{\circ} \mathrm{C}$. The experiment conducted showed that the deformation temperature is high enough to avoid ferrite nucleation, which adversely affects the strength properties. ${ }^{10,11}$ The load observed at $900{ }^{\circ} \mathrm{C}$ implies there is no occurrence of ferrite dynamic precipitation, while incomplete softening can be found with the aid of a metallographic analysis (Figures 7 and $\mathbf{8}$ ).

\section{MICROSTRUCTURE AND MECHANICAL PROPERTIES}

The microstructure obtained using accelerated cooling with mist is composed of martensite and bainite, depending on forging temperature portions of fine and narrow-spaced pearlite, differing in the fractions of the constituents. The cooling rate of $20{ }^{\circ} \mathrm{C} / \mathrm{s}$ is sufficient to omit the high-temperature onset of a diffusion-driven transformation into recrystallized austenite. Industriallike conditions of direct cooling (based on the assumption of quenching directly after deformation) caused an increased amount of ferrite, with a simultaneous increase in the fraction of martensite instead of bainite or Widmanstätten ferrite. As indicated in the physical simulation included in the study, $80^{\circ} \mathrm{s}^{-1}$ in a range of 

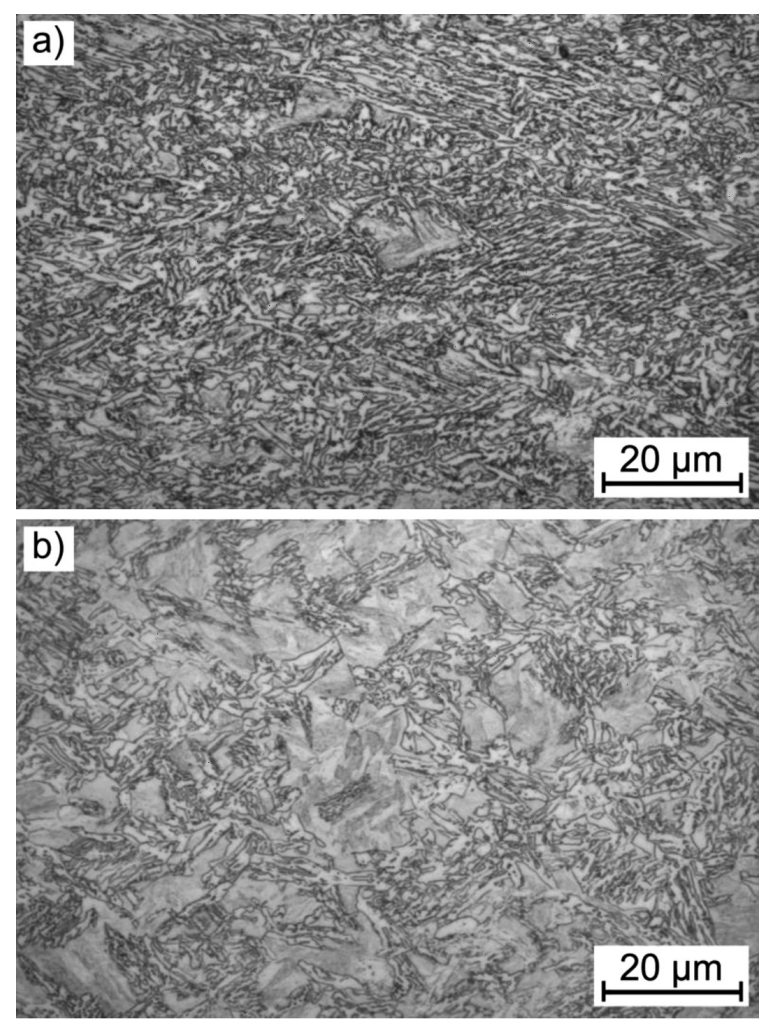

Figure 7: Microstructures of alloy A in as-forged direct-cooling conditions, after forging at: a) $1100{ }^{\circ} \mathrm{C}$, b) $900{ }^{\circ} \mathrm{C}$

Slika 7: Mikrostruktura zlitine A, ohlajene takoj po kovanju: a) $1100{ }^{\circ} \mathrm{C}$, b) $900{ }^{\circ} \mathrm{C}$

Table 3: Mechanical properties of the microalloyed steels after accelerated cooling

Tabela 3: Mehanske lastnosti mikrolegiranih jekel po pospešenem ohlajanju

\begin{tabular}{|c|c|c|c|c|c|}
\hline \multirow{2}{*}{ Alloy } & $\begin{array}{c}\text { Forging } \\
\text { tempera- } \\
\text { ture, }{ }^{\circ} \mathrm{C}\end{array}$ & $\begin{array}{c}Y S, \\
\mathrm{MPa}\end{array}$ & $\begin{array}{c}U T S, \\
\mathrm{MPa}\end{array}$ & $\begin{array}{c}\text { Elongation at } \\
\text { fracture, } A_{10} \\
\%\end{array}$ & $\begin{array}{c}\text { Area } \\
\text { reduction, } \\
\%\end{array}$ \\
\hline \multirow{2}{*}{ Steel A } & $1100{ }^{\circ} \mathrm{C}$ & 1104 & 1688 & 3.2 & 6 \\
\cline { 2 - 6 } & $900{ }^{\circ} \mathrm{C}$ & 915 & 1486 & 5.8 & 20 \\
\hline \multirow{3}{*}{ Steel B } & $1100{ }^{\circ} \mathrm{C}$ & 706 & 1208 & 9.4 & 44 \\
\cline { 2 - 6 } & $1000^{\circ} \mathrm{C}$ & 1043 & 1514 & 7.5 & 38 \\
\cline { 2 - 6 } & $900{ }^{\circ} \mathrm{C}$ & 757 & 1012 & 11.0 & 59 \\
\hline
\end{tabular}

$800-500{ }^{\circ} \mathrm{C}$ suffices to produce a $50 \%$ martensite transformation after the post-forging operations like trimming the flash and transfer on air. As shown in Figure 7, by forging at $900{ }^{\circ} \mathrm{C}$, we obtained nonrecrystallized microstructures with a high density of crystallographic defects, such as shearing bands and sub-cells with very fine grains at the grain boundaries, illustrating the increment of the total strength enhancement due to the reduction of the forging regime.

Based on comparable cooling conditions, the microstructure analysis indicated a strong effect of forging conditions on the grain size and morphology, which is reflected by mechanical properties. Steel A exhibits a higher strength, with UTSs of $1688 \mathrm{MPa}$ after the forging at $1100{ }^{\circ} \mathrm{C}$ and $1486 \mathrm{MPa}$ for $900{ }^{\circ} \mathrm{C}$ (Table 3). Steel B
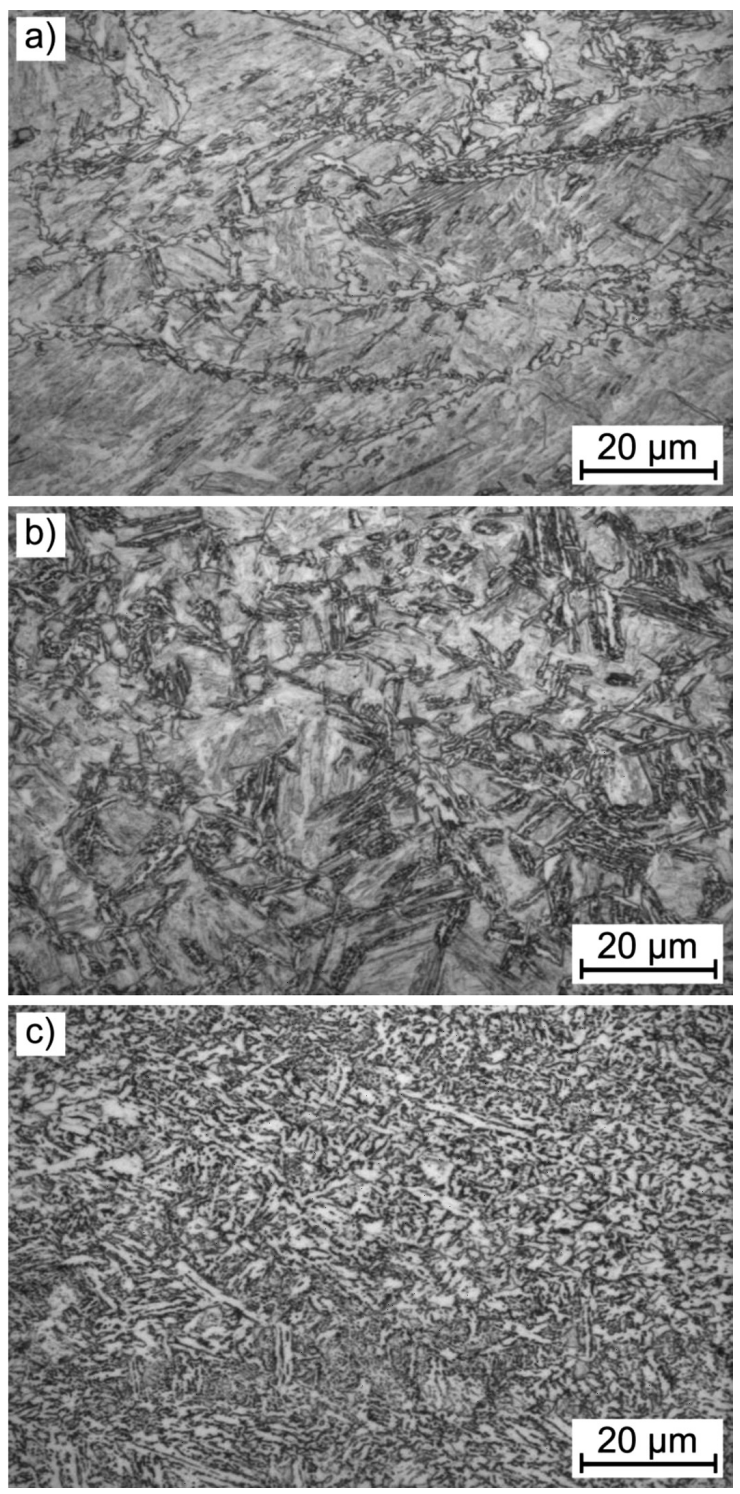

Figure 8: Microstructures of alloy $\mathrm{B}$ in as-forged direct-cooling conditions, after forging at: a) $900{ }^{\circ} \mathrm{C}$, b) $1000{ }^{\circ} \mathrm{C}$, c) $1100{ }^{\circ} \mathrm{C}$

Slika 8: Mikrostruktura zlitine $\mathrm{B}$, ohlajene takoj po kovanju na: a) $900{ }^{\circ} \mathrm{C}$, b) $1000{ }^{\circ} \mathrm{C}$, c) $1100{ }^{\circ} \mathrm{C}$

shows a better ductility associated with the Mo addition. Furthermore, directly cooled steel A showed a $5 \%$ elongation while steel B indicted an $8 \%$ elongation, which is a satisfactory result, taking into account that no tempering was carried out, while auto-tempering, enabling a ductility enhancement, could be utilized in industrial processes.

\section{CONCLUSIONS}

Deformation at a varied temperature, in connection with direct cooling, indicates a strong influence of hammer-forging conditions on the resultant mechanical properties. This gave us an opportunity for investigating 
the possibilities of controlling microstructural properties and comparing them.

According to the prevailing studies of the TMP utilization in combination with microalloyed steels, detrimental hammer-forging conditions and the required final properties make big differences. Nevertheless, hammerforging plants, as well as those employing high-speedpress forging, are quite numerous and the control and design of the TMP process in such conditions are still challenging.

Both the chemical compositions of the designed alloys and the technology based on the concept of direct cooling from the forge-end condition assure simplicity and attractiveness to the forging industry, offering reduced costs and making it possible for steelworks to keep the imposed limits of alloying elements. Moreover, the predefined cooling conditions are easily transferable to forge-plant conditions. The contents of the microalloying elements in alloys are kept within reasonable limits required from the standpoint of control of the grain-structure evolution due to the interactions of the precipitates with microstructural defects during forging and the subsequent cooling. ${ }^{12}$

The incremental character of forging, the thin end, optionally allows continuous-cooling deformation modeling. However, it may be noticed that the hook undergoes a double reduction: during the flattening and finishing of the impression. Hence, a simple compression of a $25 \mathrm{~mm}$ flat bar ensures appropriate geometrical and, more importantly, phenomenological similarity conditions. Thus, the forging tests reflected the industrial processes of both forging and cooling. Having passed the $800-500{ }^{\circ} \mathrm{C}$ range, the cooling rate was slowed down producing a type of the equalizing hold (Figures 6 and 7), reducing thermal stresses on the one hand and the time for the $\mathrm{Nb}$ carbide precipitation ${ }^{13}$ on the other hand.

Precipitates greatly contribute to the hardening of an alloy; however, the efficiency of their strengthening depends on the volume fraction and size of the precipitates. Depending on the particle relation to the dislocation parameters, it can pile up and loop the dislocations or be sheared by it. ${ }^{14}$ In the case of the analyzed alloys, both instances were witnessed. The produced carbides and carbonitrides $\mathrm{TiC}$ and $\mathrm{Ti}(\mathrm{C}, \mathrm{N})$ are of the largest size among the occurring precipitates. They are reported to take on the form of cube-like shapes, reaching a micrometer in diameter, which enabled an observation with the immersion technique using an optical microscope. On the other hand, $\mathrm{Nb}$ carbides have smaller particle diameters. They are found to have a spherical shape and the size of dozens of nanometers. Their contribution to the total strength enhancement reaches $90 \mathrm{MPa}^{13,15}$, which causes high effectiveness in pinning grain boundaries during deformation and grain-restoration processes.

The volume of these precipitates allow for a significant microstructural controllability brought about by $\mathrm{Nb}(\mathrm{C}, \mathrm{V})$, provided the whole $\mathrm{Nb}$ content dissolves at temperatures of $1170-1190{ }^{\circ} \mathrm{C}$. The applied $\mathrm{Nb}$ content is supposed to retard recrystallization, which calls for a lower forging temperature.

The overall level of the strength properties results from the grain refinement, which contributes up to $250 \mathrm{MPa} \cdot{ }^{14} \mathrm{It}$ is enhanced by the presence of $\mathrm{N}$ and $\mathrm{Al}$, lowering the tendency for coagulation of the $\mathrm{V}(\mathrm{C}, \mathrm{N})$ precipitates. In addition to reducing the amount of vanadium dissolved in the austenite ${ }^{16}$ by decreasing the selfdiffusion of iron, $\mathrm{N}$ reduces the grain-growth tendency ${ }^{17}$, as long as it is below the content necessary for the $\mathrm{VN}$ formation. ${ }^{18}$

Besides the precipitates, the grain is refined due to the grain-structure restoration during the forging, which greatly influences the concentration of nucleation sites. Decreasing the forging temperature from $1180{ }^{\circ} \mathrm{C}$ to $1000{ }^{\circ} \mathrm{C}$ resulted in lowering the forge-end point from about $1210{ }^{\circ} \mathrm{C}$ to $1034{ }^{\circ} \mathrm{C}$, producing a fine-grained structure, which formed a base for fine colonies of pearlite or bainite during the cooling. The produced microstructure exhibits a grain size decreasing with the lowering forging temperature. However, contrary to higher temperature trials, a microstructure abundant in crystallographic defects was obtained during the forging at about $900{ }^{\circ} \mathrm{C}$, such as shearing bands and non-recrystallized sub-cells with particularly fine grains at the grain boundaries, which can be attributed to discontinuous dynamic recrystallization, resulting in a selective renovation of the grains, typical of a low-temperature deformation. ${ }^{19,20}$ The presence of such grains confirms that the deformation was completed below the temperature, at which the recrystallization and/or the straininduced precipitation inhibiting static recrystallization can occur. ${ }^{21}$

The mixture of fine recrystallized and strain-hardened grains produced a significant strengthening, resulting in an UTS of $1700 \mathrm{MPa}$, similar to the related studies. ${ }^{22}$ On the other hand, a low plasticity, reaching at most $11 \%$ of $A_{10}$ elongation to fracture was obtained. However, in an industrial practice, higher plasticity indices should be expected as, in contrast to small laboratory samples, massive parts allow the auto-tempering effect to occur, enabling a ductility improvement. It must be noted that the flat specimens did not have a privileged grain-flow direction. On the contrary, the grain-flow orientation in the gauge area of the tensile specimens was perpendicular to the tension direction. In the considered part, the situation was different - the metal flow pattern produced an evident longitudinal grain flow, allowing the ductility enhancement.

\section{Acknowledgements}

Financial assistance of NCBiR within project PBS2/ $\mathrm{B} 5 / 29 / 2013$ agreement 19.19 .110 .86730 , is acknowledged. 


\section{REFERENCES}

${ }^{1}$ W. Von Karl-Wilhelm, Werkstoffentwicklung für Schmiedeteile im Automobilbau, ATZ Automobiltechnische Zeitschrift, 100 (1998) 12 918-927, doi:10.1007/BF03223434

${ }^{2}$ S. Engineer, B. Huchtemann, V. Shueler, A Review of the Development and Application of Microalloyed Medium-Carbon Steels, Proceedings of an International Symp. Fundamentals of Microalloying Forging Steels, Golden, Colorado 1986, 19-37

${ }^{3}$ A. A. Petrunenkov, K. Hulka, Niobium Technical Report, NbTR, 15 (1990), 1-22

${ }^{4}$ R. Lagneborg, O. Sandberg, W. Roberts, Fundamentals of Microalloying Forging Steels, Warrendale, 187 (1986), 39-51

${ }^{5}$ D. J. Naylor, Microalloyed Forging Steels, Materials Science Forum, 284-286 (1998), 83-94, doi:10.4028/www.scientific.net/MSF.284286.83

${ }^{6}$ P. E. Reynolds, Alternatives to conventional heat treatment for engineering steel components, Heat Treatment of Metals, 3 (1990), 69-72

${ }^{7}$ C. I. Garcia, A. K. Lis, T. M. Maguda, A. J. DeArdo, A new microalloyed, multi-phase steel for high strength forging applications, Proc. of the International Conference on Processing, Microstructure and Properties of Microalloyed and Other Modern High Strength Low Alloy Steels, Pittsburgh 1991, 395-400

${ }^{8}$ X. X. Xu, B. Z. Bai, D. Y. Liu, Y. Yuan, Effect of Thermomechanical Treatment Temperature on Structure and Properties of CFB/M Ultra-High Strength Steel, J. Iron and Steel Res. Int., 17 (2010) 4, 66-72, doi:10.1016/S1006-706X(10)60088-X

${ }^{9}$ H. K. D. H. Bhadeshia, Driving force for martensitic transformation in steels, Met. Sci., 15 (1981) 4, 175-177, doi:10.1179/ 030634581790426714

${ }^{10}$ M. Mukherjee, U. Prahl, W. Bleck, Modelling of Microstructure and Flow Stress Evolution during Hot Forging, Steel Res. Int., 81 (2010), 1102-1116, doi:10.1002/srin.201000114

${ }^{11}$ P. Skubisz, .. Lisiecki, Warm-forging characteristics and microstructural response of medium carbon high-strength steels for high-duty components, Key Eng. Mat., 611-612 (2014), 167-172, doi:10.4028/www.scientific.net/KEM.611-612.167
${ }^{12}$ P. Skubisz, A. Żak, M. Burdek, Ł. Lisiecki, P. Micek, Design of controlled processing conditions for drop forgings made of microalloy steel grades for mining industry, Arch. Metall. Mat., 60 (2015) 1, 445-453, doi:10.1515/amm-2015-0073

${ }^{13}$ A. G. Kostryzhev, A. Al Sharami, C. Zhu et al., Effect of niobium clustering and precipitation on strength of an NbTi-microalloyed ferritic steel, Mat. Sci. and Eng. A, 607 (2014), 226-235, doi:10.1016/j.msea.2014.03.140

${ }^{14}$ T. Gladman, Precipitation hardening in metals, Mat. Sci. Tech., 15 (1999) 1, 30-36, doi:10.1179/026708399773002782

${ }^{15}$ R. D. K. Misra, H. Nathani, J. E. Hartmann, F. Siciliano, Microstructural evolution in a new 770MPa hot rolled $\mathrm{Nb}-\mathrm{Ti}$ microalloyed steel, Mat. Sci. Eng. A, 394 (2005), 339-352, doi:10.1016/j.msea. 2004.11.041

${ }^{16}$ E. Głowacz, H. Adrian, W. Osuch, The nitrogen content effect on carbonitride coagulation in $40 \mathrm{Cr} 8$ steel with micro-additions $\mathrm{V}$ and V+Al, Arch. Met. Mater., 58 (2013) 2, 607-611, doi:10.2478/ amm-2013-0045

${ }^{17}$ H. Adrian, E. Głowacz, The effect of nitrogen and microalloying elements $(\mathrm{V}$ and $\mathrm{V}+\mathrm{Al})$ on austenite grain growth of $40 \mathrm{Cr} 8$ steel, Arch. Met. Mater., 55 (2010) 1, 107-116

${ }^{18}$ J. Adamczyk, E. Kalinowska-Ozgowicz, W. Ozgowicz, R. Wusatowski, Interaction of carbonitrides $\mathrm{V}(\mathrm{C}, \mathrm{N})$ undissolved in austenite on the structure and mechanical properties of microalloyed $\mathrm{V}-\mathrm{N}$ steels, J. Mat. Proc. Techn., 53 (1995) 1-2, 23-32, doi:10.1016/ 0924-0136(95)01958-H

${ }^{19}$ P. R. Spena, D. Firrao, Thermomechanical warm forging of Ti-V, Ti-Nb, and Ti-B microalloyed medium carbon steel, Mat. Sci. Eng. A, 560 (2013), 208-215, doi:10.1016/j.msea.2012.09.058

${ }^{20} \mathrm{G}$. Gao, Ch. Feng, B. Bai, Effects of $\mathrm{Nb}$ on the Microstructure and Mechanical Properties of Water-Quenched FGBA/BG Steels, J. Mat. Eng. Perf., 21 (2012) 3, 345-352, doi:10.1007/s11665-011-9903-6

${ }^{21}$ J. Kliber, R. Fabik, I. Vitez, K. Drozd, Hot forming recrystallization kinetics in steel, Metalurgija, 49 (2010) 1, 67-71

${ }^{22}$ X. Kong, L. Lan, Optimization of mechanical properties of low carbon bainitic steel using TMCP and accelerated cooling, Proc. Eng., 81 (2014), 114-119, doi:10.1016/j.proeng.2014.09.136 